NASA Technical Memorandum 105195

AIAA-91-3481

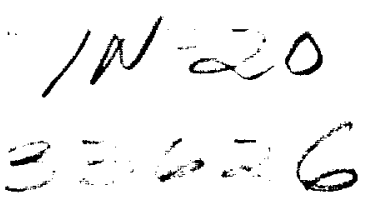

\title{
Production and Use of Metals and Oxygen for Lunar Propulsion
}

Aloysius F. Hepp and Diane L. Linne

National Aeronautics and Space Administration

Lewis Research Center

Cleveland, Ohio

Geoffrey A. Landis

Sverdrup Technology, Inc.

Lewis Research Center Group

Brook Park, Ohio

Mary F. Groth

National Aeronautics and Space Administration

Lewis Research Center

Cleveland, Ohio

and

James E. Colvin

University of Arizona

Tuscon, Arizona

Prepared for the

Conference on Advanced Space Exploration Initiative Technologies cosponsored by the AIAA, NASA, and OAI

Cleveland, Ohio, September 4-6, 1991 



\section{PRODUCTION AND USE OF METALS AND OXYGEN FOR LUNAR PROPULSION}

\author{
Aloysius F. Hepp, Diane L. Linne, \\ National Aeronautics and Space Administration \\ Lewis Research Center \\ Cleveland, Ohio 44135 \\ Geoffrey A. Land is \\ Sverdrup Technology, Inc. \\ Lewis Research Center Group \\ Brook Park, Ohio 44142
}

\begin{abstract}
This paper discusses production, power and propulsion technologies for using oxygen and metals derived from lunar resources. The production process is described, and several of the more developed processes are discussed. Power requirements for chemical, thermal, and electrical production methods are compared. The discussion includes potential impact of ongoing power technology programs on lunar production requirements. This study also compares the performance potential of several possible metal fuels including aluminum, silicon, iron, and titanium. Space propulsion technology in the area of metal/oxygen rocket engines is discussed.
\end{abstract}

\section{INTRODUCTION}

Utilization of resources available in situ is a critical enabling technology for manned space exploration. The ultimate success of a permanent lunar base will depend upon the use of available resources. The purpose of this paper is to discuss in situ resources and processing options from the perspective of available power and propulsion technologies and potential contributions to be made by the relevant programs at the NASA Lewis Rescarch Center.

The topics of lunar resources ${ }^{1}$ and processing of lunar resources ${ }^{3-12}$ have been explored often in the recent scientific and technical literature. There is no atmosphere or water on the moon; two important products obtainable from available lunar resources are oxygen and metals. Oxygen can be used for both life support and as an oxidizer for rocket engines; metals can be used as power materials, as structural materials, and as fuels for rocket engines. Lunar samples returned from the Apollo and Luna missions indicate that approximately 45 percent by weight of the lunar surface material is oxygen. 'Much of this oxygen is in the form of silicates and other mixedmetal oxides. Oxygen is the clear choice as an in situ oxidizer because of its prevalence on the moon and the accumulated experience in rocket engine combustion. The choice for a fuel, however, is less apparent. The most common elements used in rocket fuels, hydrogen and

\author{
Mary F. Groth ${ }^{\dagger}$ \\ National Aeronautics and Space Administration \\ Lewis Research Center \\ Cleveland, Ohio 44135 \\ and \\ James E. Colvin \\ University of Arizona \\ Tuscon, Arizona 85721
}

carbon, are not available in appreciable amounts. Because of this, interest has turned to lunar metals as a potential source of fuel.

There are many benefits to be realized by using indigenous materials for propellants. The most significant is the reduction in initial mass in low-Earth orbit (LEO). When launch costs to orbit are counted in thousands of dollars per pound of payload, a reduction in the mass required from Earth can be translated to a significant cost savings For lunar missions, a large portion of the initial mass in LEO is the propellant to take the vehicle to the moon and the propellant to return from the moon. If the propellant to return can be manufactured at the moon; not only does this mass no longer need to be raised to LEO, but the propellant to transport it to the moon is also saved. 2

Most propulsion systems used today operate at oxidizer to fuel ratios greater than one; producing only oxygen at the moon will show significant reduction in initial mass in LEO. Mission analyses have predicted a 40 to 60 percent reduction if oxygen is produced at the moon to operate with Earth-supplied hydrogen for all near-lunar and Earth return propulsive maneuvers. ${ }^{2}$ Because almost all oxygen on the moon is in the form of metal oxides, ${ }^{1}$ the production of oxygen will necessarily produce metals as a co-product. If these metals are used as fuel, then further reductions in initial mass in LEO can be obtained. While this additional reduction in initial mass in LEO may not be as significant as that obtained from in situ-produced oxygen, other benefits can be achieved when both propellants are obtained on the lunar surface. One of these benefits is a reduction in mission complexity because vehicle refueling can be performed in the 1/6th gravity environment of the lunar surface instead of the microgravity environment in lunar orbit. Another benefit is the establishment of true self-sufficiency of a lunar base.

\section{LUNAR RESOURCES}

A wealth of information about lunar resources was obtained during the era of intensive American and Soviet lunar exploration by Ranger, Lunar Orbiter, Surveyor and Apollo (U.S.) and Luna and Zond (U.S.S.R.) missions. Table 1 lists the missions that produced geological,

+ - Member, AIAA. 
mineralogical, and/or chemical information. An excellent, recently published source contains much of the data presented in this discussion of lunar resources. ${ }^{1}$ Experiments that were performed included: surface chemistry, atmosphere and ion studies, dust analysis, meteoroid studies, and soil mechanics studies. There was a total of $381.7 \mathrm{~kg}$ of samples returned by Apollo missions and $0.3 \mathrm{~kg}$ retumed by Luna missions. There is also information derived from lunar meteorites found on the Antarctic ice cap.

In situ lunar resources can be subcategorized as four different classes of material: ${ }^{1}$ (1) mare basalic volcanic rocks (composed of lava and volcanic ash); (2) pristine highland rocks (original lunar composition unaffected by impact mixing); (3) complex breccias and impact melts (with mixed original lunar and meteoric composition); and (4) lunar regolith composed of unconsolidated debris.

TABLE 1.

SUMMARY OF GEOLOGICAL, MINEROLOGICAL, AND CHEMICAL INFORMATION-PRODUCING U.S. AND SOVIET LUNAR MISSIONS*

\begin{tabular}{llll} 
MISSION & $\begin{array}{c}\text { DATE } \\
\text { LAUNCHED }\end{array}$ & $\begin{array}{c}\text { DATA } \\
\text { OBTAINED }\end{array}$ & $\begin{array}{c}\text { SAMPLE } \\
\text { MASS }\end{array}$ \\
\hline Luna 10 & $03 / 31 / 66$ & $\mathrm{O}$ & \\
Luna 13 & $12 / 21 / 66$ & $\mathrm{C}$ & \\
Surveyor 5 & $09 / 08 / 67$ & $\mathrm{C}$ & \\
Surveyor 6 & $11 / 07 / 67$ & $\mathrm{C}$ & \\
Surveyor 7 & $01 / 07 / 68$ & $\mathrm{C}$ & \\
Apollo 11 & $07 / 16 / 69$ & $\mathrm{~S}$ & $21.6 \mathrm{~kg}$ \\
Apollo 12 & $11 / 14 / 69$ & $\mathrm{~A}, \mathrm{~S}$ & $34.3 \mathrm{~kg}$ \\
Luna 16 & $09 / 12 / 70$ & $\mathrm{~S}$ & $100 \mathrm{~g}$ \\
Luna 17 & $11 / 10 / 70$ & $\mathrm{C}$ & \\
Apollo 14 & $01 / 31 / 71$ & $\mathrm{~A}, \mathrm{~S}$ & $42.3 \mathrm{~kg}$ \\
Apollo 15 & $07 / 26 / 71$ & $\mathrm{~A}, \mathrm{C}, \mathrm{O}, \mathrm{S}$ & $77.3 \mathrm{~kg}$ \\
Luna 20 & $02 / 14 / 72$ & $\mathrm{~S}$ & $30 \mathrm{~g}$ \\
Apollo 16 & $04 / 16 / 72$ & $\mathrm{~A}, \mathrm{C}, \mathrm{O}, \mathrm{S}$ & $95.7 \mathrm{~kg}$ \\
Apollo 17 & $12 / 07 / 72$ & $\mathrm{~S}$ & $110.5 \mathrm{~kg}$ \\
Luna 21 & $01 / 08 / 73$ & $\mathrm{C}$ & \\
Luna 24 & $08 / 09 / 76$ & $\mathrm{~S}$ & $170 \mathrm{~g}$ \\
\hline
\end{tabular}

- See Tables 2.1 and 2.2, text reference [1]. Abbreviations: A: Atmospheric Data; C: Surface Chemistry; O: Chemical Analysis from Orbiting Vehicle; $S:$ Returned Samples. Boldface indicates manned missions; italics indicates orbiting, not landing, mission.

Table 2 lists the name and chemical formulas of the most imporant or potentially useful mineral structural types found on the moon. Specific mineral names are included for chemically pure compounds. These often represent endpoints or corners of phase diagrams. The actual minerals found are solid solutions of the chemically pure compounds and may be doped with other metal ions of like charge or size. Lunar rocks and soils are composed of mixtures of silicates and mixed metal oxides (major phases) and metal sulfides and native metals (minor phases). The geological, mineralogical and chemical data derived from the 16 lunar missions that yielded such information and over 2000 samples, are quite complex. The following discusses composition of in situ resources with a focus on propellant production.

TABLE 2.

MOST COMMON OR POTENTIALLY USEFUL MINERAL TYPES FOUND ON THE MOON (INCLUDING SPECIFIC MINERAL COMPOUNDS)

NAME Silicate Minerals

$\begin{array}{cl}\text { 1. Pyroxene } & \left(\mathrm{Ca}, \mathrm{Fe}, \mathrm{Mg}_{2} \mathrm{Si}_{2} \mathrm{O}_{6}\right. \\ \text { Enstatite } & \mathrm{MgSiO}_{3} \\ \text { Wollastonite } & \mathrm{CaSiO}_{3} \\ \text { Ferrosilite } & \mathrm{FeSiO}_{3} \\ \text { 2. Plagioclase Feldspar } & \left(\mathrm{Ca}, \mathrm{Na}^{2}(\mathrm{Al}, \mathrm{Si})_{4} \mathrm{O}_{8}\right. \\ \text { Albite } & \mathrm{NaAlSi}_{3} \mathrm{O}_{8} \\ \text { Anorthite } & \mathrm{CaAl}_{2} \mathrm{Si}_{2} \mathrm{O}_{8} \\ \text { 3. Olivine } & \left(\mathrm{Mg}_{3} \mathrm{Fe}\right)_{2} \mathrm{SiO}_{4} \\ \text { Fayalite } & \mathrm{Fe}_{2} \mathrm{SiO}_{4} \\ \text { Forsterite } & \mathrm{Mg}_{2} \mathrm{SiO}_{4}\end{array}$
4. Imenite Oxide Minerals
Geikielike
Ilmenite
$(\mathrm{Fe}, \mathrm{Mg}) \mathrm{TiO}_{3}$
5. Spinel
Chromite
Ulvöspinel
Hercynite
Spinel
6. Armalcolite
Ferropseudobrookite
Karrooite
$\mathrm{MgTiO}_{3}$
$\mathrm{FeTiO}_{3}$
$(\mathrm{Fe}, \mathrm{Mg})(\mathrm{Cr}, \mathrm{Al}, \mathrm{Ti})_{2} \mathrm{O}_{4}$
$\mathrm{FeCr}_{2} \mathrm{O}_{4}$
$\mathrm{Fe}_{2} \mathrm{TiO}_{4}$
$\mathrm{FeAl}_{2} \mathrm{O}_{4}$
$\mathrm{MgAl}_{2} \mathrm{O}_{4}$
$(\mathrm{Fe}, \mathrm{Mg}) \mathrm{Ti}_{2} \mathrm{O}_{5}$
$\mathrm{FeTi}_{2} \mathrm{O}_{5}$
$\mathrm{MgTi}_{2} \mathrm{O}_{5}$

$\begin{array}{ll}\text { 7. Troilite } & \\ \text { 8. Iron/Nickel Alloys } & \mathrm{FeS} \\ \text { Kamacite } & (\mathrm{Fe}, \mathrm{Ni}) \\ \text { Taenite } & \text { (Fe, Ni) }(\mathrm{Ni}<0.06) \\ \text { Tetrataenite } & \text { (Fe, Ni) }(0.06<\mathrm{Ni}<0.5) \\ & \mathrm{FeNi}\end{array}$

Mare basaltic rocks and glasses found on volcanic plains are relatively rich in ilmenite, spinel, and armalcolite. This explains the high concentration of iron oxide. Titanium oxide concentration is variable but generally much higher than found in highland regions. ${ }^{1}$ The remaining composition of mare basalts (70 to 90 percent) consists of plagioclase and pyroxene. This accounts for the relatively lower abundance of $\mathrm{SiO}_{2}, \mathrm{CaO}$ and $\mathrm{Al}_{2} \mathrm{O}_{3}$ when compared to highland rocks and breccia. The relatively large amounts of oxides in mare basalts provides a potential source of both iron and titanium. 
Highland pristine rocks are of mainly three types. ${ }^{1}$ Ferroan anorthosites are mostly plagioclase feldspar with small amounts of pyroxene and olivine. These rocks are quite rich in $\mathrm{Ca}$ and $\mathrm{Al}$ as expected from the chemical formula of both feldspars. Four other pristine rocks, Gabbros, Norites, Troctolites, and Dunites, are described as $\mathrm{Mg}$-rich rocks and contain more pyroxene and olivine. Dunite, for example, is almost pure olivine, accounting for its high concentration of $\mathrm{MgO}$. Troctolites are also composed of relatively higher concentrations of olivine accounting for 20 percent MgO. Finally, KREEP (see footnote in table 3 below) rocks are basaltic lavas with relatively high concentrations (by lunar standards) of potassium and rare earth oxides and phosphorus.

Breccias and impact melts form a class of materials that range in appearance from homogeneous to composite-like. This is due to the various impact, melting and cooling processes that result in their formation. The breccias in general consist of clast (fragments) and the matrix that contains them. ${ }^{1}$ The majority of the material in various breccias are similar to the pristine rocks, hence the similarities in composition. One potential use for breccias may be as a source of rare platinum-group metals derived from meteoric materials.

The lunar regolith, having been disintegrated by mechanical weathering, may be an important source of $\mathrm{FeO}$ and $\mathrm{Al}_{2} \mathrm{O}_{3}$ that requires a minimum of mechanical processing. Finally, lunar regolith (as well as some lunar rocks ${ }^{\text {) }}$ is a source of metal powder and alloys (see table 2). Though a minor component, reduced metals may prove to be an important, easy-to-obtain iron source.

Representative oxide compositions for typical rock and soil samples collected on the moon are listed in table 3. Examples listed are representative of material returned from the Apollo and Luna missions.

Finally, it must be noted that the geological exploration of the moon to date has sampled only an insignificant fraction of the surface at an extremely superficial level. Further exploration will almost certainly reveal mineral types, elements, and concentrations as yet unsuspected.

\section{PROCESSING TECHNOLOGY}

Taking advantage of the abundance of metal oxides on the lunar surface as potential sources of in situ propellant compounds requires that areas where these raw materials are readily available be identified. The raw material must then be mined and subjected to a beneficiation process to separate the desired feedstock to supply the particular process scheme to manufacture the propellant elements. Potential propellant elements include $\mathrm{O}_{2}, \mathrm{Al}, \mathrm{Fe}, \mathrm{Si}$, and $\mathrm{Ti}$. Many processes have been proposed for the production of oxygen and metals from the lunar resources. ${ }^{3-12}$ Most of these have terrestrial counterparts; some have evolved to take advantage of unique characteristics of the lunar environment.
TABLE 3.

\section{APPROXIMATE CHEMICAL COMPOSITION OF SAMPLED LUNAR MATERIALS*}

\begin{tabular}{lrrrrrr} 
MATERIAL ** & $\mathrm{SiO}_{2}$ & $\mathrm{FeO}$ & $\mathrm{CaO}$ & $\mathrm{TiO}_{2}$ & $\mathrm{Al}_{2} \mathrm{O}_{3}$ & $\mathrm{MgO}$ \\
& \multicolumn{7}{c}{ Mare Basalis } \\
High-Ti & 40 & 19 & 11 & 11 & 10 & 7 \\
Low-Ti & 46 & 21 & 10 & 3 & 9 & 10 \\
Al low-Ti & 46 & 17 & 11 & 3 & 14 & 9 \\
Very-low-Ti & 46 & 22 & 12 & 1 & 12 & 6 \\
Orange Glass & 39 & 22 & 8 & 9 & 6 & 14 \\
Green Glass & 44 & 21 & 8 & 1 & 8 & 17
\end{tabular}

Highland Pristine Rocks

\begin{tabular}{|c|c|c|c|c|c|c|}
\hline moan & & & & & & \\
\hline Anorthosites & 45 & 3 & 17 & 0 & 31 & 3 \\
\hline Gabbros & 5 & 10 & 12 & 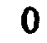 & 13 & 13 \\
\hline Norites ${ }^{\circ e *}$ & 51 & 10 & 9 & 0 & 1 & 13 \\
\hline Troctolites" & 43 & 5 & 11 & 0 & 20 & 20 \\
\hline Dunites" & 40 & 12 & 1 & 0 & 1 & 45 \\
\hline KREEP & 52 & 10 & 9 & 2 & 16 & 8 \\
\hline
\end{tabular}

\begin{tabular}{llllllr}
\multicolumn{8}{c}{ Complex Breccias and Impact Melts } \\
Fragmental & 45 & 3 & 17 & 0 & 30 & 3 \\
Glassy Melt & 45 & 5 & 15 & 0 & 27 & 7 \\
Crystalline & 48 & 8 & 11 & 1 & 18 & 13 \\
Clast-Poor & 47 & 7 & 13 & 1 & 22 & 8 \\
Granulitic & 45 & 5 & 15 & 0 & 27 & 7
\end{tabular}

Apollo 12 Site Apollo 14 Site Apollo 15 Site Apollo 16 Site Apollo 17 Site Lunar Regolith

$\begin{array}{rrlllr}46 & 15 & 11 & 3 & 13 & 9 \\ 48 & 10 & 11 & 2 & 17 & 9 \\ 47 & 14 & 11 & 1 & 15 & 12 \\ 45 & 5 & 16 & 1 & 27 & 6 \\ 43 & 12 & 12 & 4 & 17 & 10\end{array}$

- From text reference 1. The five most prevalent oxides generally account for $>97 \%$ by weight; the remaining oxides are manganese, sodium, potassium, chromium, rare earth oxides and other, generally at less than one-half percent abundance. " - Weight fractions listed are composites of several samples from one site or from one mission. *.* - Example of a rock-type referred to as magnesium rich. **** - High concentration potassium $(\mathrm{K})$, rare earth oxide (ree), and phosphorus $(P)$ rock, accounts for approximately 3 to 4 percent, by weight.

Mining techniques on the moon will be necessarily different from their terrestrial counterparts. The major difference is that on the earth conventional mining depends on the abundant water supply for cooling and lubrication, movement and separation of materials, and solution and precipitation of metals. Another difference in lunar mining is the fact that throughout lunar geological history it has been subjected to many meteor impacts. This has led to a homogenization of the soils, making the regolith a mixture of many rock and mineral types. ${ }^{1.3}$ 
Because of this difference, the mining philosophy on the moon should involve mining the rocks for their common elements.

On earth most ores are recovered below the surface, while on the moon it is worthwhile to consider surface mining. This method would take advantage of the fact that, due to numerous meteor impacts, surface material is mostly pulverized, helping to reduce mechanical processing of rocks before beneficiation. Other advantages of surface mining the moon are: totally visible operations, lower gravity (implying easier material transport), and lack of weather or a corrosive atmosphere. One disadvantage is that the moon experiences a 14-day sunlit period followed by 14 days of darkness. This could be a problem if considering solarderived power for the operation. Additionally, extreme temperature contrasts also accompany this day-night cycle, leading to problems with lubrication, friction, and equipment failure. ${ }^{3}$

Once raw materials have been mined, feedstocks for various processing techniques need to be separated from the mined material. This process is called beneficiation and performs the function of concentrating the desired metal oxides. There are two major beneficiation techniques, magnetic and electrostatic. ${ }^{5}$ Magnetic beneficiation is accomplished by feeding the raw material through the field of one or more magnets. This will cause separation of magnetic minerals from non-magnetic materials. The use of magnets with different field strengths further separates the magnetic minerals. Electrostatic separation is more complex, but has the advantage of being able to separate non-magnetic minerals. This process is used to separate materials with respect to their conductive properties: conducting, semiconducting, or insulating. Most minerals will show some difference in conductive properties.

There is presently a variety of processing schemes available for potential use on the lunar surface whose products can be used as propellants. Table 4 lists several of the more studied processes. ${ }^{3-12}$ Although lunar processing methods will model terrestrial modes of operation, there are several concerns that must be considered when processing operations are conducted on the moon. ${ }^{6}$ First, there is no air or water, thus depriving the plant of heat sinks provided by these fluids. Traditional energy sources are absent (i.e. coal, oil, or gas). Basic processing chemicals are absent (i.e. ammonia, salt, chlorine, soda ash, carbon dioxide etc.). Finally, since initially there will be no local human operators, the plant will have to be autonomous.

One conclusion that may be drawn from table 4 is that titanium production from lunar materials is quite difficult, requiring large amounts of energy. This is consistent with the stability of the six titanium-oxygen

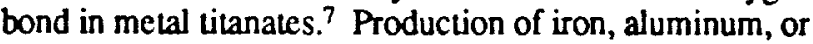
silicon can be optimized by proper choice of processing method and is dependent upon the feedstock; silicon, found in tetrahedral coordination, is easiest to reduce. When anorthite is the feedstock, silicon and aluminum in the same coordination environment are obtained similarly from this aluminosilicate. In silicates and mixed systems such as regolith, however, silicon is much casier to reduce than aluminum or iron as the latter two metals are mostly found in six-fold coordination sites. ${ }^{1}$ Iron is more easily obtained from reduction of ilmenite ${ }^{13,14}$ while aluminosilicates are better sources of aluminum as mentioned above. $16,17,20$

The four example metals were chosen because they are relatively abundant on the moon, can be obtained by a known terrestrial process, and are candidates for lunarderived propellants. The particular method(s) and metal(s) chosen will be a function of the feasibility of the process on the moon (processing materials and power requirements), potential utility of the metal as a propellant (and other applications), and mass trade-offs for the plant requirements and terrestrial-derived substitutes.

Processing methods in table 4 are listed in order of technology readiness. ${ }^{7}$ Methods that are most developed have terrestrial counterparts. These methods are compatible with the use of solar thermal heating, discussed below, and solar- or nuclear-generated electricity. Unfortunately, these methods often involve use of terrestrial-derived materials such as $\mathrm{HF}, \mathrm{Na}, \mathrm{Li}, \mathrm{C}$, $\mathrm{F}_{2}$, or $\mathrm{Cl}_{2}$. Methods that are compatible with space processing involve very high temperatures and relatively large amounts of power. For such methods, nuclear power is most likely to be the source of the needed processing power. New power tochnologies may enable the use of relatively high-power options that take advantage of the unique lunar processing environment.

\section{POWER TECHNOLOGY}

For any manned mission, a significant priority for a power system will be reliability and absence of dangerous failure modes. Due to the high price of transporting materials to the moon, an additional priority for a surface power system will be low weight. For lunar resource processing, two types of power are needed: thermal energy and electric energy. Depending on the processing technology chosen, the relative amount of thermal and electrical process power required can vary considerably. It is much more efficient to use a primary thermal energy source than to produce thermal power from electricity.

There are two main power sources to be considered for the moon: solar and nuclear. A third alternative, the use of lasers to beam power to photovoltaic arrays from remote locations either in orbit or on the Earth, ${ }^{27.28}$ will not be discussed here. The 354-hour lunar night requires that any solar power system either shut down during the night, or include a large storage system for continuous power. ${ }^{27}$ In general, the power levels for resource utilization are so high that energy storage for night operation is not likely to be practical. 
TABLE 4.

LUNAR PROCESSING METHODS*

PROCESS

FEEDSTOCK

ELECT. THERMAL

POWER POWER TEMP PRODUCTS ${ }^{* *}$ (kW/t fuel $(\mathrm{kW} / \mathrm{t}$ fuel / year) ${ }^{* *} \quad /$ year $)^{* *}$

$\left({ }^{\circ} \mathrm{C}\right)$

FUEL

\begin{tabular}{|c|c|c|c|c|c|}
\hline Hydrogen Reduction?,13,14 & Imenite $\left(\mathrm{FeTiO}_{3}\right)$ & 0.72 & 0.18 & 900 & $\begin{array}{l}\mathrm{O}_{2}, \mathrm{Fe}, \mathrm{FeO}, \mathrm{TiO}_{2} \\
\mathrm{Fe}\end{array}$ \\
\hline Carbothermal ${ }^{6-10,15,16}$ & Enstatite $\left(\mathrm{MgSiO}_{3}\right)$ & 0.82 & 3.28 & 1625 & $\begin{array}{l}\mathrm{O}_{2}, \mathrm{Si}, \mathrm{MgO}, \mathrm{SiH}_{4} \\
\mathrm{Si}\end{array}$ \\
\hline Carbochlorination ${ }^{4,12,16,17}$ & Anorthite $\left(\mathrm{CaAl}_{2} \mathrm{Si}_{2} \mathrm{O}_{8}\right)$ & $\begin{array}{l}1.33 \\
1.38 \\
\end{array}$ & $\begin{array}{l}2.46 \\
2.57 \\
\end{array}$ & $675-770$ & $\begin{array}{l}\mathrm{O}_{2}, \mathrm{CaO}, \mathrm{Al}, \mathrm{Si} \\
\mathrm{Si} \\
\mathrm{Al}\end{array}$ \\
\hline HF Acid Leaching $6,8,10,12$ & Mare Regolith & 8.85 & 8.85 & 110 & $\mathrm{O}_{2}, \mathrm{Al}$ \\
\hline Reduction by $\mathrm{Li}$ or $\mathrm{Na}^{5,18,19}$ & Mare Regolith & $\begin{array}{r}2.15 \\
3.30 \\
14.55 \\
\end{array}$ & $\begin{array}{r}2.15 \\
3.30 \\
14.55 \\
\end{array}$ & 900 & $\begin{array}{l}\mathrm{O}_{2}, \mathrm{Si}, \mathrm{Fe}, \mathrm{Ti} \\
\mathrm{Si} \\
\mathrm{Fe} \\
\mathrm{Ti}\end{array}$ \\
\hline Reduction by $\mathrm{Al}^{5,7,12,20}$ & Anorthite $\left(\mathrm{CaAl}_{2} \mathrm{Si}_{2} \mathrm{O}_{8}\right)$ & $\begin{array}{l}2.56 \\
2.64 \\
\end{array}$ & $\begin{array}{l}0.64 \\
0.66 \\
\end{array}$ & 1000 & $\begin{array}{l}\mathrm{O}_{2}, \mathrm{Si}, \mathrm{Al}, \mathrm{Ca} \\
\mathrm{Si} \\
\mathrm{Al}\end{array}$ \\
\hline Direct Fluorination $3,4,11,21$ & Anorthite $\left(\mathrm{CaAl}_{2} \mathrm{Si}_{2} \mathrm{O}_{8}\right)$ & $\begin{array}{l}15.52 \\
16.16 \\
\end{array}$ & $\begin{array}{l}3.88 \\
4.04 \\
\end{array}$ & 900 & $\begin{array}{l}\mathrm{O}_{2}, \mathrm{Al}, \mathrm{Si}, \mathrm{CaO} \\
\mathrm{Si} \\
\mathrm{Al}\end{array}$ \\
\hline Magma Electrolysis $4,22,23$ & Silicate Rock & 0.26 & 0.26 & $1000-1500$ & $\begin{array}{l}\mathrm{O}_{2}, \mathrm{Fe} \\
\mathrm{Fe}\end{array}$ \\
\hline Fluxed Electrolysis ${ }^{6,8,24}$ & Silicate Rock & $\begin{array}{c}6.40 \\
9.95 \\
19.15 \\
\end{array}$ & $\begin{array}{c}6.40 \\
9.95 \\
19.15 \\
\end{array}$ & $1000-1500$ & $\begin{array}{l}\mathrm{O}_{2}, \mathrm{Al}, \mathrm{Si}, \mathrm{Fe} \\
\mathrm{Si} \\
\mathrm{Fe} \\
\mathrm{Al} \\
\end{array}$ \\
\hline $\begin{array}{l}\begin{array}{l}\text { Vaporization/Fractional } \\
\text { Distillation } 7.12,25,26\end{array} \\
\end{array}$ & Regolith & $\begin{array}{l}1.77 \\
5.28 \\
\end{array}$ & $\begin{array}{r}4.13 \\
12.32 \\
\end{array}$ & 2700 & $\begin{array}{l}\mathrm{O}_{2}, \mathrm{Al}, \mathrm{Si}, \text { Suboxides } \\
\mathrm{Si} \\
\mathrm{Al}\end{array}$ \\
\hline Selective Ionization $4 ., 12,25$ & Regolith & $\begin{array}{l}7.90 \\
12.20 \\
23.60 \\
52.00 \\
\end{array}$ & & 7700 & $\begin{array}{l}\mathrm{O}_{2}, \mathrm{Al}, \mathrm{Si}, \mathrm{Fe}, \mathrm{Ti}, \mathrm{Mg} \\
\mathrm{Si} \\
\mathrm{Al} \\
\mathbf{F e} \\
\mathbf{T i}\end{array}$ \\
\hline
\end{tabular}

- Methods ranked in order of technical "readiness" as defined by text ref. 7, with the most mature technologies at the top. Normal text indicates terrestrial-derived processes; highlighted text indicates space-derived processes. "* - Process power requirements dependent on desired metal product (ref. 7). Some thermal power estimates may not include the power needed to reach processing temperature, such as selective ionization. "** - Products produced by the listed method include the major metal -containing species and oxygen. 
Many of the proposed processing technologies assume that processing will be done as a continuous flow system. ${ }^{411}$ However, in view of the fact that the majority of material processing done on Earth is done in batch processes, and that lunar processing is most likely to use Earth-derived technology, it is reasonable to assume that batch processing is the more likely mode of operation, at least for initial operations. For example, if solar power is used, the necessity to shut down processing for the 14-day lunar night, would require no additional process changes.

Thermal power can be produced either from a solar furnace, by the direct use of nuclear heat, or from electrical power. Solar concentrator mirrors designed for solar thermal power on Earth have demonstrated the ability to produce the high temperatures needed for most of the thermally-demanding processes proposed for the moon. A solar concentrator for use in space has been designed for the solar dynamic power system, proposed for space station Freedom. This system is designed to operate at about $750^{\circ} \mathrm{C} \cdot .^{10,11}$ For these systems, the heated region is at the focus of the mirror, and moves as the mirror tracks the sun. Since lunar resource processing equipment is likely to be heavy, a system designed for the moon would not have the concentrating mirror track the sun. A separate tracking mirror (or "heliostat") would be used to reflect the sun to stationary concentrator mirrors.

If a reactor is used for primary electrical power, one option would be to use the same reactor to direclly produce thermal power for resource processing. To date, little discussion has been made of this possibility. The SP-100 nuclear reactor has a working-fluid operating temperature of about $1000^{\circ} \mathrm{C} .{ }^{29}$ (Higher temperatures can be produced intemally, depending on the materials used; for example, nuclear thermal rockets operate at temperatures of several thousand degrees.) Radioactivity associated with the reactor means that the reactor site is likely to be located several kilometers from any locations associated with manned activity. This would therefore require that either the processing be entirely autonomous, or that hot working fluid be piped over relatively long distances to a site compatible with man-tended operation.

Use of electrical power to produce heat is inefficient. However, an advantage of electrical heaters is that a base will require an electrical power system in any case, and it may be easier to scale up an existing power system to high powers than to design a new system. Electrical power may be produced either by a nuclear reactor or by solar panels. A nuclear power system for use on the moon based on the SP-100 reactor would deliver $100 \mathrm{~kW}$ of electrical power from a $2.5 \mathrm{MW}$ thermal reactor for a baseline system. ${ }^{29}$ Replacing the low-efficiency thermoelectric converters by high efficiency Stirling engines would result in a power level of $\sim 825 \mathrm{~kW}$ from the baseline reactor. The mass of this reactor system would be about $20000 \mathrm{~kg}$. Higher power levels could be oblained either by increasing the number of reactors, or designing a higher power reactor.
An alternative source of electrical power is solar panels; several technology efforts are underway to improve solar panel technology. Photovoltaics provide low-cost power with high reliability and no moving parts. It has powered the space program since Vanguard, and there is every reason to believe it will play a major role in any long-term manned presence on the moon. Some of the design considerations involved in choosing photovoltaic power systems for a lunar base are discussed in recent references. ${ }^{30,31}$ For an advanced system, it may be possible to use solar cells manufactured on the moon. ${ }^{32}$

There are three approaches to photovoltaic power. The conventional approach is the use of deployable highefficiency flat plate arrays. Existing solar arrays used in space use either crystalline silicon (Si) or gallium arsenide (GaAs) solar cells. Silicon is the most well developed solar cell technology, and has been used on all but a tiny fraction of space solar arrays. The conversion efficiency of standard-technology silicon cells currently flown is about 14\% under standard space conditions ("Air Mass Zero," or "AM0"). Up to $20 \%$ conversion efficiency has been demonstrated in the laboratory, but such cells are not yet space qualified and not currently available on the market. Note that for calculating operational power, all efficiency numbers must be adjusted for the array packing efficiency and corrected for intensity and temperature effects. An advantage of silicon cells is that large area cells are available $(8$ by $8 \mathrm{~cm}$ cells will be used for Freedom). The array technology is well developed and well characterized, both in the laboratory and from inspace use, for vibration, thermal-cycling, and other environmental loads of the space environment.

Gallium arsenide cells have higher efficiency than $\mathrm{Si}$ cells. Cells currently available on the market have an average conversion efficiency of $18.5 \%$. Efficiency of $21.5 \%$ has been achieved in the laboratory. Gallium arsenide cells are smaller and more brittle than silicon cells, but the technology is being rapidly developed. Gallium arsenide cells are currently heavier than silicon cells, however, several technologies under development will make GaAs cells much lighter in weight. The most well-developed of these technologies is cleaved lateral epitaxy for film transfer (CLEFT), where an extremely thin ( 5 micron) large-area cell can be separated from a single-crystal substrate.

An altemative approach to photovoltaic arrays for use in space is the use of extremely thin layers of photovoltaic material deposited onto a flexible substrate. This approach has lower conversion efficiencies, but has the potential for higher specific power, at least at the blanket level. This has not yet been demonstrated in space. This approach uses thin-film solar cell technology which has been developed for low-cost terrestrial solar arrays. Efficiencies around ten percent have been achieved with three thin-film materials: amorphous silicon (a-Si), copper indium diselenide ( $\mathrm{CuInSe}_{2}$ ), and cadmium telluride (CdTe). However, very little current research is aimed at depositing thin-film cells on lightweight substrates, since most of the applications being considered are terrestrial, where weight is not as critical. To enable their use on the 
moon, technology for deposition on extremely lightweight substrates will need to be developed.

A final photovoltaic approach is to use a concentrator system to focus light onto small, extremely high efficiency solar cells. This approach has been tested in space only in small-scale experiments. In the laboratory, conversion efficiencies of over $30 \%$ have been demonstrated using such concentrator systems and highefficiency tandem solar cells.

Of importance to power system analysis is the specific power (power output per unit mass). Note that it is possible to measure specific power at the cell level, at the blanket level, at the array level, or at the power system level. Specific power at the cell level does not include array structure and is many times higher than array level specific power. At the blanket level, specific power includes the cover-glass, interconnections, and the backing material, but not the array structure. This may be appropriate, however, if a flexible or semi-flexible array is to be simply unrolled horizontally onto the lunar surface without support structure. Specific power at the photovoltaic array level (including array structure) for the best arrays developed to date are shown in table 5 .

TABLE 5. SPECIFIC POWER OF SOLAR ARRAYS (EARTH ORBIT SOLAR INTENSITY)

$\begin{array}{lc} & \text { SPECIFIC } \\ \text { SYSTEM } & \text { POWER }\end{array}$

Best Flight Tested Array

Solar Array Flight Experiment

(SAFE)

$66 \mathrm{~W} / \mathrm{kg}$

Best Currently Built Array

Advanced Pholovoltaic Solar Array

(APSA)

$130 \mathrm{~W} / \mathrm{kg}$

Best Array Combining Existing

Technology APSA with $20 \%$

CLEFT GaAs cells

$300 \mathrm{~W} / \mathrm{kg}$

For currently designed space power systems, e.g., for the space station Freedom solar array, the photovoltaic blanket weight is only about a quarter of the total power generation system mass (excluding batteries used for electrical storage). The array plus structure accounts for half of the power system mass. The power management and distribution (PMAD) system accounts for the remaining half of the power system mass. This provides a powerful incentive to develop new and more efficient PMAD systems and to design new array structures to take advantage of ulura-light blankets.

\section{PROPULSION TECHNOLOGY}

The final selection of production methods will depend greaty on the determination of which are the most useful products. The theoretical performance of several metals burned with oxygen was determined using a one dimensional chemical equilibrium computer code. ${ }^{33}$ This code predicts specific impulse assuming the maximum energy release possible in the combustion chamber less chamber dissociation losses. Figure 1 shows this predicted performance for aluminum, titanium, silicon, and iron as a function of mixture ratio, chamber pressure and expansion area ratio.

Figure la shows the effect on specific impulse for aluminum/oxygen at a chamber pressure of 3000 psia as area ratio increases from 10 to 500 and as mixture ratio increases from 0.3 to 4.0 . The results for a chamber pressure of 200 psia are shown only for an area ratio of 10 as a representation of the small effect that chamber pressure has on ideal specific impulse. The maximum predicted impulse of aluminum/oxygen is approximately 315 seconds at a chamber pressure of 3000 psia and an area ratio of 500 .

Figure $1 \mathrm{~b}$ shows similar curves for the titanium/oxygen combination. The discontinuity in the curves is caused by a change in the predominant oxide formed in the combustion chamber. For titanium/oxygen, the maximum predicted impulse is approximately 285 seconds at a chamber pressure of 3000 psia and area ratio of 500 .

Figure 1c shows the same curves for the silicon/oxygen combination. While the maximum specific impulse is nearly as high as that predicted for the aluminum/oxygen, the curve shown for a chamber pressure of 200 psia and an area ratio of 10 indicates increased sensitivity to chamber pressure. For this propellant combination, there is a difference of more than 10 seconds in predicted specific impulse at a chamber pressure of 200 and 3000 psia. This is an indication that the silicon dioxide products have high rates of dissociation at lower pressures. The high dissociation rates could become a significant problem when finite-rate kinetics are considered in the calculations.

Figure 1d shows the same curves for the ironloxygen propellant combination. The maximum impulse predicted for the iron is only 210 seconds at a chamber pressure of 3000 psia and area ratio of 500 . While lower engine performance can be tolerated from an in situ propellant combination because of the benefits of obtaining the propellant at the destination, mission analyses have shown that 210 seconds is too low for iron fuel to be seriously considered as an alternative.

While one-dimensional equilibrium predictions provide adequate comparisons when evaluating potential propellants, a more rigorous theoretical analysis would need to be performed to accurately predict the specific impulse that an actual engine would deliver. Factors that may degrade performance from the ideal values discussed above include incomplete energy release in the chamber due to incomplete mixing of fuel and oxidizer or incomplete burning of the metal particles, finite-rate chemical reactions, growth of a viscous boundary layer in the chamber and nozzle, and thermal or velocity nonequilibrium between the solid and gaseous combustion products. Some losses, such as finite-rate kinetics, cannot 


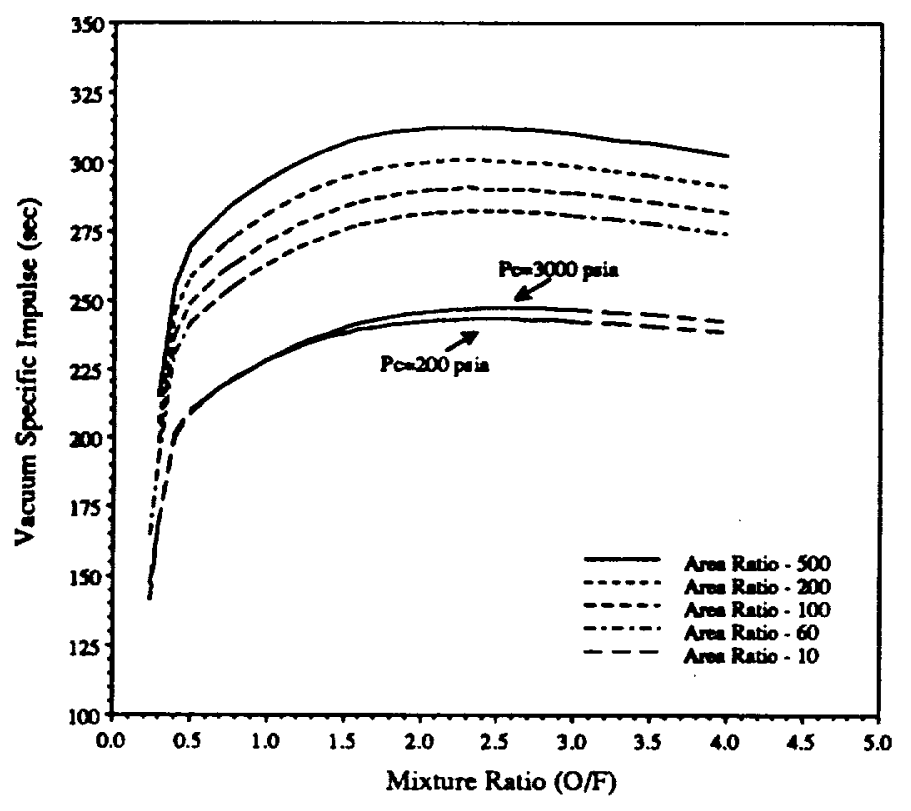

(a) Aluminum/Oxygen.

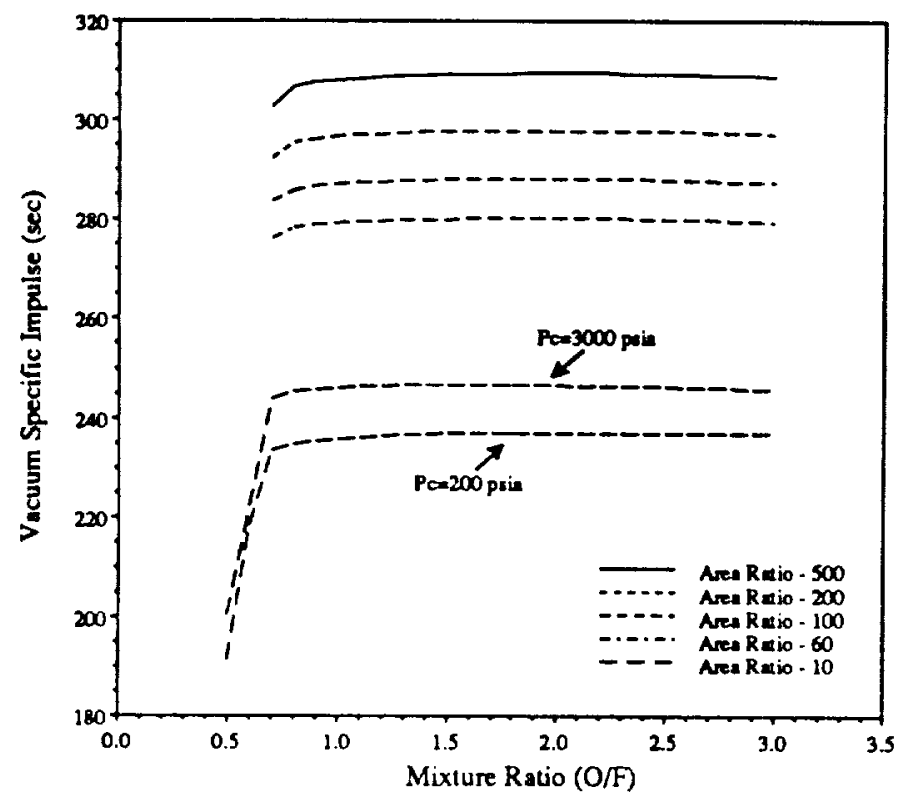

(c) Silicon/Oxygen.

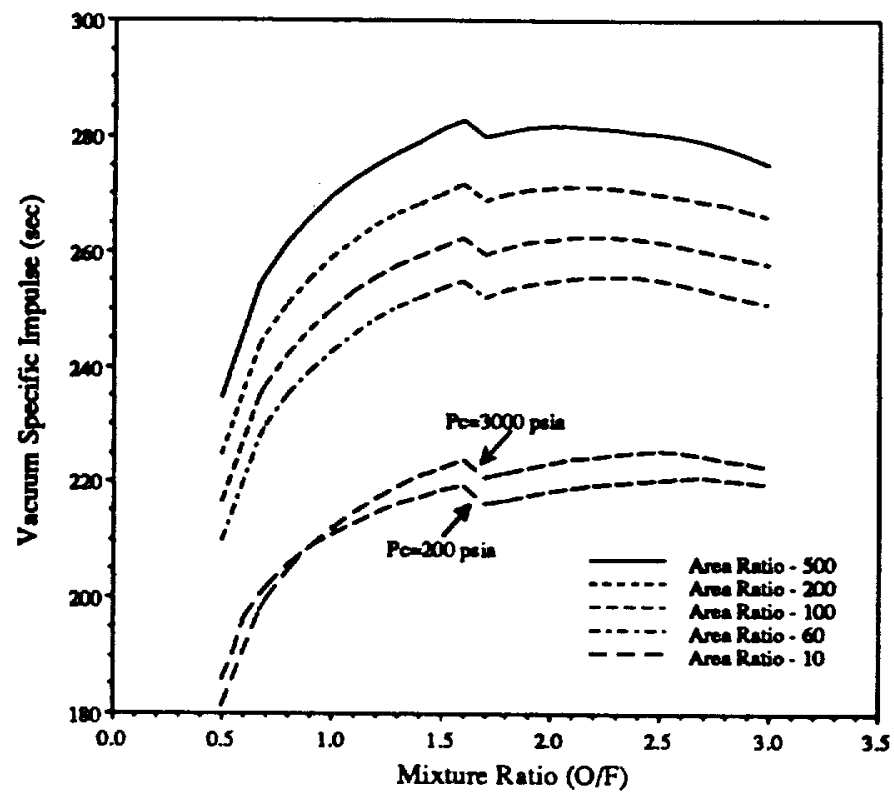

(b) Titanium/Oxygen.

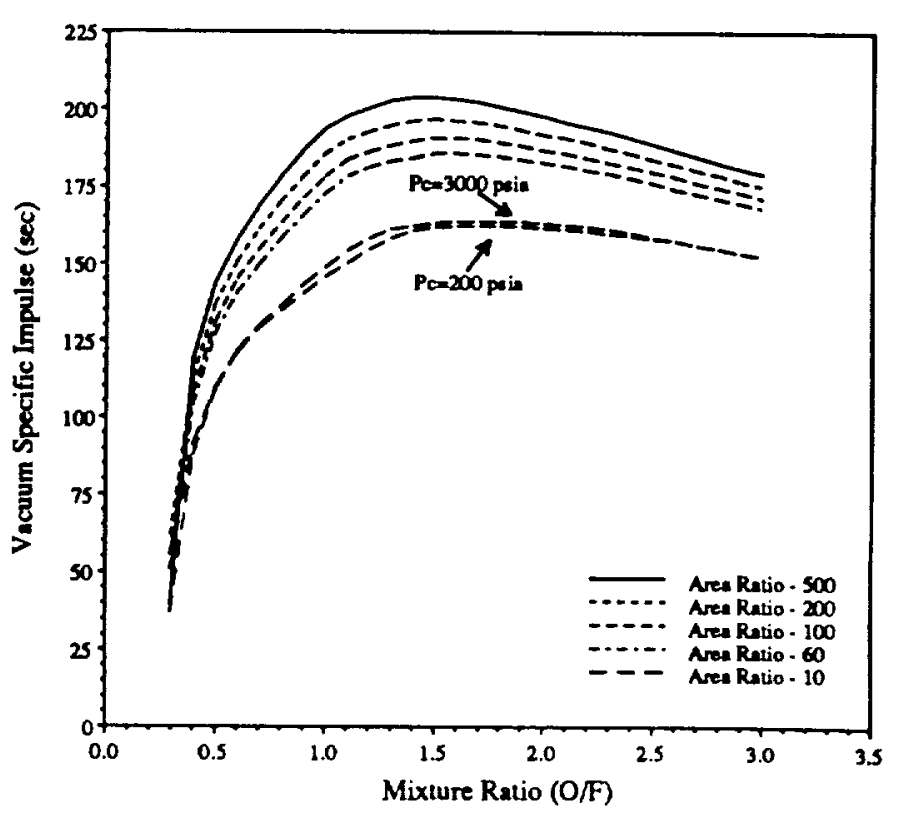

(d) Iron/Oxygen.

Figure 1.-Theoretical vacuum specific impulse performance of lunar inigenous propellants assuming one-dimensional equilibrium. 
be changed or reduced. Other losses, such as incomplete mixing in the chamber and boundary layer growth, can be reduced by proper hardware design. Finally, losses such as incomplete burning of the metal particles and two phase flow effects can be reduced by proper fuel design. Technology efforts have been initiated to reduce those loss mechanisms that can be affected by hardware or fuel design.

A program is underway to establish the technology base needed for the development of engines that utilize indigenous resources at the moon. The metal and oxygen propellants can be used as either a monopropellant, with powdered metal suspended in the liquid oxygen, or as a bipropellant, with a conventional liquid oxygen feed system and a pneumatic feed system for the powdered fuel. A monopropellant could be potentially hazardous; a hazards assessment and propellant formulation must be completed before any combustion experimentation can begin. Meanwhile, single particle ignition studies offer insights into the ignition mechanism of the metal particles.

The objective of the hazards assessment activity is to assign an explosive classification to the monopropellant so that the associated safe handling procedures can be used. A preliminary goal of the hazards assessment is to test small, laboratory-scale quantities for explosive hazards such that formulation research can begin with assurances of safety. To accomplish this preliminary goal, two phases of the hazards assessment program have been completed.

The first phase consisted of mixing tests, where small amounts of the metal powders and liquid oxygen were combined and then stirred at low speeds (approximately $600 \mathrm{rpm}$ ) while being monitored for any signs of chemical reaction. A total of 63 tests were performed with aluminum, titanium, silicon, and iron powders, with and without a gellant; no chemical reactions were observed. ${ }^{34}$

The second phase consisted of mechanical impact tests, where a weight was dropped into a small sample of the monopropellant from various heights to determine the necessary energy to cause a reaction. The results were reported in terms of a 50 percent height, which is the weight height at which a reaction occurred 50 percent of the time. PETN, which is a solid Class A explosive known to be impact sensitive, was used as a reference material in the test apparatus. The 50 percent height of the PETN was $51.0 \mathrm{~cm}$ (impact energy of 45.4 joules). The 50 percent height of the titanium was less than 15.2 $\mathrm{cm}$ (13.6 joules), which was the lowest height available in the test apparatus. The 50 percent height of an $80 \%$ $\mathrm{Al} / 20 \% \mathrm{Mg}$ alloy was $67.6 \mathrm{~cm}$ ( 60.1 joules). The 50 percent heights of the aluminum, silicon, and iron were all greater than $123.0 \mathrm{~cm}$ (109.4 joules), which was the highest height available in the test apparatus. For all metal powders except titanium, the results of the mechanical impact tests indicated that it is safe to handle the powders in the quantities and manners necessary to begin formulation and characterization of the monopropellant. ${ }^{35}$
The objective of the monopropellant formulation task is to determine the minimum amount of gellant required to stably suspend the metal particles in the liquid oxygen, while maintaining acceptable flow properties. Preliminary efforts have indicated that this can be accomplished with as little as two percent by weight of the gellant (amorphous fumed silica). A secondary objective of the formulation and characterization task was to determine the bum rate of the monopropellant. If the monopropellant burns faster than the injection velocity into the chamber, then burming could propagate into the feed lines and the propellant tank, causing catastrophic failure. The burn rate tests were conducted with the monopropellant submerged in a liquid nitrogen bath to prevent boil-off of the liquid oxygen before the start of the test. During the test, this nitrogen acted as a heat sink, absorbing the energy created by the combustion of the monopropellant. Because of this rapid heat transfer, the monopropellant combustion was unable to sustain itself after the solid propellant ignition charge was removed. Therefore, the ambient pressure burn rate of monopropellants at liquid nitrogen temperatures approaches zero, assuring that the flame will not propagate into feed lines

Research into the ignition and burning of single metal particles in a hot oxygen environment has been started in an effort to reduce potential performance losses. From experience with metal fuels in solid rocket motors and from theoretical calculations, it is known that two keys to reducing performance losses are quick ignition of the metal particles and vapor phase or explosive combustion that minimizes the size of the solid products. To achieve these goals, various aluminum/magnesium alloys are being tested in a shock tube. It is expected that magnesium in an alloy will ignite more quickly than aluminum; differences in boiling temperatures will help promote the vapor phase or explosive combustion. Results from these experiments can be used in future design of rocket engines that use metal/oxygen propellants. Although metals have not been used before as the sole fuel element, the technology work being performed indicates that a metal/oxygen monopropellant or bipropellant may make a suitable propellant combination for indigenous use at the moon.

\section{CONCLUSIONS}

The case for in situ propellant production is a powerful one. ${ }^{2}$ However, it is clear that advances must occur in the areas of production, power, and propulsion technology. Lunar resources are available to provide the necessary metals and oxygen. While our knowledge of the lunar surface and its geology, mineralogy, and chemistry is extensive, further exploration will be required to fully exploit lunar resources for manned exploration and colonization.

Production technology must be developed to take advantage of the lower gravity, sunlight, relative vacuum, and desolation of the moon. Lunar production processes must depend as liule as possible on non-renewable earth- 
derived chemicals. The power must be obtainable from solar or nuclear sources and be compatible with the intended use of the energy, thermal or electrical. The power source itself could be derived from local resources, for example silicon solar cells on the moon. ${ }^{32}$

$A$ joint Power and Space Propulsion effort is underway at NASA Lewis Research Center to address issues relaied to both propellant production and use. The aim of this effort is to insure systems integration at the research end to minimize problems at the working systems end. It is noteworthy that an integrated approach to production and utilization of in situ resources is also underway for manned missions to Mars. ${ }^{36,37}$

By obtaining all of the propellants for near-lunar operation on the moon's surface, significant benefits for future manned lunar missions can be realized. It is also expected that mission architectures will include plans for lunar-derived propellants to fuel further exploration to Mars. It is therefore important for a coherent approach by the exploration community for in situ resource utilization in terms of technology for lunar and Mars resource exploitation. Such an effort is also underway at the University of Arizona's Space Engineering Research Center. ${ }^{38}$ The Power and Space Propulsion Divisions at NASA Lewis Research Center will continue to contribute to basic technologies for manned exploration into the twenty-first century.

\section{REFERENCES}

1. Lunar Sourcebook, Heiken G., Vaniman, D. and French, B.M. (eds.), Cambridge University Press: Cambridge, UK, 1991. There are numerous primary resources referenced; as the discussion of lunar exploration and geology is beyond the scope of this paper, the reader is referred to this source.

2. Wickman, J.H., Obert, A.E. and Mockenhaupt, J.D., "Lunar Base Spacecraft Propulsion with Lunar Propellants," at AIAA/ASME/SAE/ASEE 22nd Joint Propulsion Conference, Huntsville, AL, June 1986, Paper AJAA-86-1763.

3. Burt, D.M., "Mining The Moon," American Scientist, 77, 574-579 (1989).

4. Steurer, W.H., "Extraterrestrial Materials Processing," JPL Publication 82-41 (1982).

5. Christianson, E.L. et al., "Conceptual Design of a Lunar Oxygen Pilot Plant, "Eagle Report No. 88-182, Final Repon for NAS9-17878 (1988).

6. Criswell, D.R. and Waldron, R.D., "Chemical Processing of Lunar Materials," presented at 30th IAF Congress, September, 1979, Munich, West Germany, Paper IAF-79-116.

7. Stancati, M.L., Jacobs, M.K., Cole, K.J., and Collins, J.T., "In Situ Propellant Production: Alternatives for Mars Exploration," SAIC-91/1052, Final Report for NAS3-25809 (1991).
8. Waldron, R.D., Erstfeld, T.E., and Criswell, D.R., "Overview of Methods for Extraterrestrial Materials Processing," in Space Manufacturing 3, Grey, J. and Krop, C. (eds.), American Institute of Aeronautics and Astronautics: Washington, D.C., 1979, pp. 113127.

9. Phinney, W.C., Criswell, D.R., Drexler, E. and Garmirian, J., "Lunar Resources and Their Utilization," Prog. Astronaut. Aeronaut., 57, pp. 97 123 (1977); also in Space Manufacturing 2, Grey, J. (ed.), American Institute of Aeronautics and Astronautics: Washington, D.C., 1977, pp. 171-182.

10. Waldron, R.D. and Criswell, D.R., "Materials Processing in Space," in Space Industrialization. Vol. 1, O'Leary, B. (ed.), CRC Press, Inc., pp. 97 130 (1982).

11. Research on the Use of Space Resources, Carroll, W. F. (ed.), JPL Publication No. 83-36, (1983).

12. Astronautics Corporation of America, "Lunar Surface Base Propulsion Study," Final Report for NAS9-17468 (1987).

13. Gibson, M.A. and Knudsen, C.W. , "Lunar Oxygen Production from Ilmenite," in Lunar Bases and Space Activities of the 21st Century, Mendell, W.W. (ed.), Lunar and Planetary Institute: Houston, TX, 1985, pp. 543-550.

14. Williams, R.J., "Oxygen Extraction from Lunar Materials: An Experimental Test of an Ilmenite Reduction Process," in Lunar Bases and Space Activities of the 21st Century, Mendell, W.W. (ed.), Lunar and Planetary Institute: Houston, TX, 1985, pp. 551-558.

15. Cutler, A.H. and Krag, P., "A Carbothermal Scheme for Lunar Oxygen Production," in Lunar Bases and Space Activities of the 21st Century, Mendell, W.W. (ed.), Lunar and Planetary Institute: Houston, TX, 1985, pp. 559-569.

16. Rosenberg, S.D., Guter, G.A. and Miller, FE., "The On-site Manufacture of Propellant Oxygen from Lunar Resources," Aerospace Chemical Engineering, 62, No. 61, 228-234 (1966).

17. Rao, B.D., Choudary, U.V. Erstfeld, T.E., Williams, R. J. and Chang, Y.A., "Extraction Processes for the Production of Aluminum, Titanium, Iron, Magnesium, and Oxygen from Non-terrestrial Sources," in Space Resources and Space Setllements, Billingham, J. and Gilbreath, W. (eds), NASA SP-428, pp. 257-274 (1979).

18. Sammells, A.F. and Semkow, K.W., "Electrolytic Cell for Lunar Ore Refining and Electric Energy Storage," presented at 2nd Symposium on Lunar Bases and Space Activities in the 21st Century, Houston, TX, April, 1988, Paper LBS-88-017.

19. Semkow, K.W. and Sammells, A. F., "The Indirect Electrochemical Refining of Lunar Ores," $J$. Electrochem. Soc., 134, 2088-2089 (1987). 
20. Anthony, D.L., Cochran, W.C., Haupin, W.E., Keller, R. and Larimer, K.T., "Dry Extraction of Silicon and Aluminum from Lunar Ores," presented at 2 nd Symposium on Lunar Bases and Space Activities in the 21st Century, Houston, TX, April, 1988, Paper LBS-88-066.

21. Burt, D.M., "Lunar Mining of Oxygen Using Fluorine," presented at 2nd Symposium on Lunar Bases and Space Activities in the 21st Century, Houston, TX, April, 1988, Paper LBS-88-072.

22. Kesterke, D.G., "Electrowinning of Oxygen from Silicate Rocks," U. S. Bureau of Mines Report of Investigations 7587 (1971); also, Proceedings of the Seventh Annual Working Group on Extraterrestrial Resources, NASA SP-229, pp. 139-145 (1970).

23. du Fresne, E. and Schroeder, J. E., "Magma Electrolysis," in Research on the Use of Space Resources, Carroll, W. F. (ed.), JPL Publication No. 83-36 (1983).

24. Rao, G.M., Elwell, D. and Feigelson, R.S., "Electrowinning of Silicon from $\mathrm{K}_{2} \mathrm{SiF}_{6}$-Molten Fluoride Systems," J. Electrochem. Soc., 127, 19401944 (1980).

25. Steurer, W.L. and Nerad, B.A., "Vapor Phase Reduction," in Research on the Use of Space Resources, Cartoll, W. F. (ed.), JPL Publication No. 83-36 (1983).

26. Sparks, D.R., "Vacuum Reduction of Extraterrestrial Silicates," Journal of Spacecraft and Rockets, 25, 187-189 (1988).

27. Landis, G.A., "Solar Power for the Lunar Night," in Space Manufacturing 7, Faughnan, B. and Maryniak, G. (eds.), American Institute of Aeronautics and Astronautics: Washington, D.C., 1989, pp. 290-296. Also available as NASA Technical Memorandum TM-102127 (1989).

28. Landis, G.A., "Moonbase Night Power by Laser Illumination," to be published, J. Propulsion and Power, 7 (1991).

29. Mason, L.S., Bloomfield, H.S. and Hainley, D.C., "SP-100 Power System Conceptual Design for Lunar Base Application," NASA TM-102090 (1989).
30. Landis, G.A., Bailey, S.G., Brinker, DJ. and Flood, DJ, "Photovoltaic Power for a Lunar Base," Acta Astronautica, 22, 197-203 (1990). Also presented at 40th IAF Congress, Torremolinos, Spain, October, 1989, Paper LAF-89-254.

31. Hickman, J.M., Landis, G.A. and Curtis, H.B., "Design Considerations for Lunar Base PV Power Systems," in Proceedings of 21st IEEE Photovoltaic Specialists Conference, Orlando, FL, May 1990. Vol. 2, 1256-1262. Also NASA TM-106342 (1990).

32. Landis, G.A. and Perino, M.A., "Lunar Production of Solar Cells: a Near-Term Product for a Lunar Industrial Facility," in Space Manufacturing 7. Faughnan, B. and Maryniak, G. (eds.), American Institute of Aeronautics and Astronautics: Washington, D.C., 1989, pp. 144-151. Also available as NASA TM-102102 (1989).

33. Gordon, S. and McBride, B.J., "Computer Program for Calculation of Complex Chemical Equilibrium Compositions, Rocket Performance, Incident and Reflected Shocks, and Chapman-Jouguet Detonations," NASA SP-273 (1976).

34. Woods, S.S., "Liquid-Oxygen/Metal Gelled Propellants Hazards Analysis (Phase I)," NASA TR625-001, NASA JSC White Sands Test Facility, Las Cruces, NM, January, 1990.

35. Rathgeber, K. and Beeson, H., "LOX/Metal Gel Mechanical Impact Test Special Test Data Report," WSTF No. 90-24223-28, 90-24490-91, January. 1991.

36. Hepp, A.F., Landis, G.A. and Linne, D.L., "Material Processing With Hydrogen and Carbon Monoxide on Mars," in Space Manufacturing 8, American Institute of Aeronautics and Astronautics: Washington, D.C., in press. Also available as NASA TM-104405 (1991).

37. Landis, G.A. and Linne, D.L., "Acetylene Fuel from Atmospheric $\mathrm{CO}_{2}$ on Mars," J. Spacecraft and Rockets, in press.

38. Ramohalli, K.N.R. and Sridhar, K.R., "Extraterrestrial Materials Processing and Related Phenomena," at 22th Aerospace Sciences Meeting. Reno, NV, January, 1991, Paper AIAA-91-0309. Also, J. Propulsion and Power, in press. 


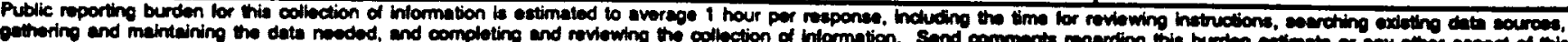

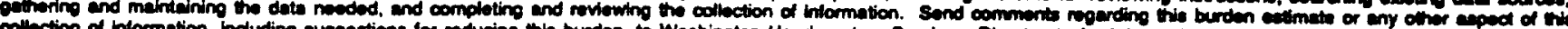

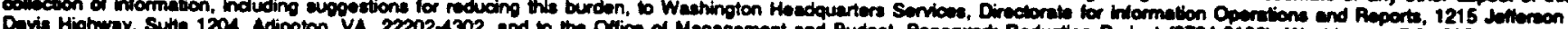

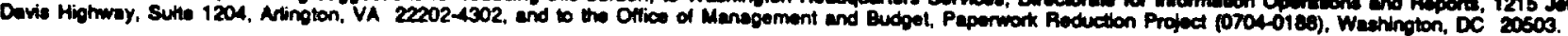
1. AGENCY USE ONLY (Laeve blank) 2. AEPOAT DATE
3. REPOAT TYPE AND DATES COVERED
Technical Memorandum

4. TITLE AND SUBTTTLE

Production and Use of Metals and Oxygen for Lunar Propulsion

5. FUNDINO NUMBERS

AUTHOR(S)

WU - 506-41-11

Aloysius F. Hepp, Diane L. Linne, Geoffrey A. Landis, Mary F. Groth, and James E. Colvin

7. PERFoRMINO OROANIZATION NAME(S) AND ADDRESS(ES)

8. PERFoRMING OROANUzATION REPORT NUMBER

National Aeronautics and Space Administration

Lewis Research Center

Cleveland, Ohio 44135 - 3191

E-6496

๑. SPONSORING/MONITORINO AOENCY NAMES(S) AND ADDRESS(ES)

10. SPONSORINGMONITORINO AOENCY REPORT MUMBEA

National Aeronautics and Space Administration

Washington, D.C. 20546-0001

NASA TM -105195

11. SUPPLEMENTARY NOTES

Prepared for the Conference on Advanced Space Exploration Initiative Technologies cosponsored by the AlAA, NASA, and OAI, Cleveland, Ohio,

September 4-6, 1991. Aloysius F. Hepp, Diane L. Linne, and Mary F. Groth, NASA Lewis Research Center. Geoffrey A. Landis, Sverdrup Technology, Inc., Lewis Research Center Group, 2001 Aerospace Parkway, Brook Park, Ohio 44142. James E. Colvin, University of Arizona, Tuscon, Arizona 85721. Responsible person, Aloysius F. Hepp, (216) 433-3835.

12a. DISTRIBUTION/AVAILABILITY STATEMENT

Unclassified - Unlimited

Subject Categories 20 and 44

13. ABSTRACT (Moximum 200 words)

This paper discusses production, power and propulsion technologies for using oxygen and metals derived from lunar resources. The production process is described, and several of the more developed processes are discussed. Power requirements for chemical, thermal, and electrical production methods are compared. The discussion includes potential impact of ongoing power technology programs on lunar production requirements. This study also compares the performance potential of several possible metal fuels including aluminum, silicon, iron, and titanium. Space propulsion technology in the area of metal/oxygen rocket engines is discussed.

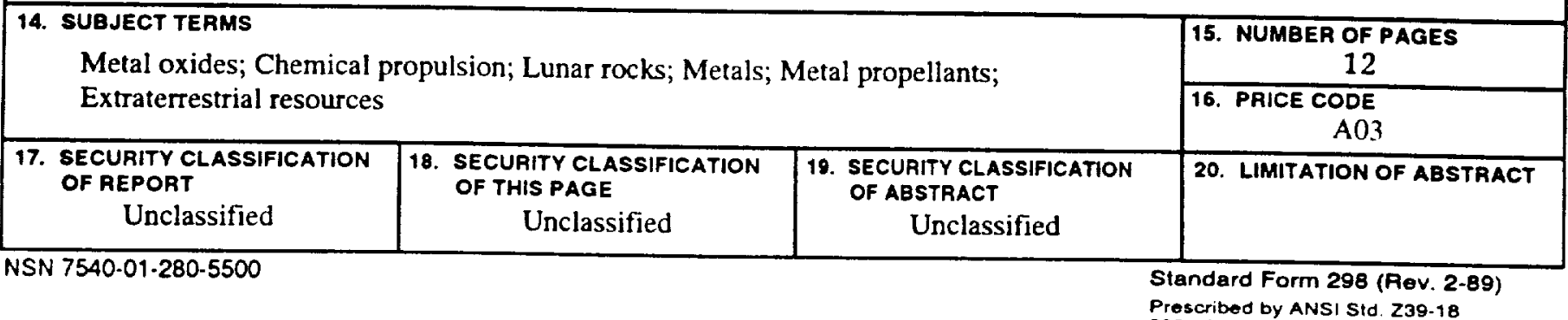


National Aeronautics and Space Adminiatration

Lowls Research Conter

Cleveland, Ohio 44135

Omelad Bualnewe

Penemy for Privels Ues swo
Foumm CLAss mall

ADORESS CORRECTION REOUESTED
|||||

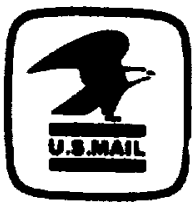

Poslage and $F$ ees Paid Nationai Aeronaulics and Space Adininisiration NASA 45 ! 